\title{
KEBIJAKAN PERLINDUNGAN HUKUM TERHADAP DOKTER DI RUMAH SAKIT DALAM PELAKSANAAN PELAYANAN JAMINAN KESEHATAN NASIONAL
}

\author{
Komar Hanifi \\ Prodi Magister Manajemen Rumah Sakit Pascasarjana Unisba \\ Komarhanifi376@gmail.com \\ DOI: https://doi.org/10.29313/sh.v16i2.4893
}

\begin{abstract}
ABSTRAK
Pelayanan JKN menimbulkan problem medis dan yuridis bagi dokter di rumah sakit yang berpotensi melanggar hukum dan tidak memperoleh perlindungan hukum. Metode penelitian menggunakan pendekatan yuridis normatif, dengan data sekunder yang dianalisis secara kualitatif dengan metode kepustakaan. Tujuan penelitian (1) untuk mengetahui pelaksanaan pelayanan medis oleh dokter di rumah sakit berdasarkan ketentuan JKN (2) bentuk kebijakan perlindungan hukum bagi dokter di rumah sakit. Hasil penelitian (1) Pelaksanaan pelayanan medis berdasarkan ketentuan JKN menempatkan dokter pada situasi dilematis karena harus memberikan pelayanan berdasarkan clinical pathway yang alur tata klinisnya ditetapkan berdasarkan pola tariff INA CBGs. Kondisi ini membuat dokter sulit memperoleh hak untuk memberikan pelayanan medis menurut standar profesi dan standar prosedur operasional sebagaimana diatur dalam Pasal 50 huruf b dan mempersempit kesempatan dokter untuk menjalankan kewajiban memberikan pelayanan medis. (2) Kebijakan perlindungan hukum bagi dokter adalah (a) perlindungan hukum preventif berupa pembuatan PNPK tatalaksana yang sudah disesuaikan dengan kebijakan pola tarif INA CBGs dan pembuatan SPM sesuai dengan tipologi rumah sakit (b) kebijakan perlindungan hukum terhadap dokter di rumah sakit dalam melaksanakan pelayanan medis sesuai ketentuan JKN adalah dengan mengadakan upaya mediasi oleh MKDKI secara independen dan otonom agar menilai tuntutan hukum yang diajukan pasien atau keluarganya.
\end{abstract}

Kata Kunci: Dokter, Rumah Sakit, JKN, Perlindungan Hukum.

\section{ABSTRACT}

JKN services cause medical and juridical problems for doctors in hospitals that have the potential to violate the law and do not get legal protection. The research method uses a normative juridical approach, with secondary data analyzed qualitatively by the literature method. Research objectives (1) to determine the implementation of medical services by doctors in hospitals based on the provisions of JKN (2) the form of legal protection policies for doctors in hospitals. The results of the study (1) The implementation of medical services based on JKN provisions puts doctors in a dilemma because they have to provide services based on clinical pathways whose clinical governance flow is determined based on the INA CBGs tariff 
pattern. This condition makes it difficult for doctors to obtain the right to provide medical services according to professional standards and operational procedure standards as regulated in Article 50 letter b and narrow the doctor's opportunity to carry out the obligation to provide medical services. (2) Legal protection policy for your doctor (a) Preventive legal protection in the form of management PNPK that has been adjusted to the INA CBG tariff pattern policy and SPM making in accordance with hospital typology (b) legal protection policy for doctors in hospitals in carrying out services medical according to $\mathrm{JKN}$ provisions is to conduct mediation efforts by MKDKI independently and autonomously to assess the lawsuits filed by patients or their families.

Keywords: Exoneration Clause, Binding Strength, Contracting Freedom

\section{A. PENDAHULUAN}

\section{Latar Belakang Masalah}

Kebijakan penetapan pembiayaan dalam pelayanan JKN menuntut rumah sakit untuk memberikan pelayanan kesehatan yang bermutu dan terjangkau sesuai standar pelayanan medis dan standar prosedur operasional. Sistem INA-CBGs diatur dalam Peraturan Menteri No 27 Tahun 2014 tentang Sistem Case Base Groups (INA-CBGs) yang telah menetapkan paket pembiayaan untuk setiap kelompok penyakit tertentu sehingga biayanya telah diketahui sebelum pelayanan diberikan. Petunjuk teknis Sistem Indonesian Case Base Groups (INA-CBGs) merupakan acuan bagi fasilitas kesehatan tingkat lanjutan, BPJS Kesehatan dan pihak lain yang terkait mengenai metode pembayaran INA-CBGs dalam pembayaran penyelenggaraan Jaminan Kesehatan. ${ }^{1}$

Persoalan muncul ketika pada kasus-kasus tertentu biaya pelayanan kesehatan yang telah ditentukan nominal dan fasilitas pelayanan medisnya tidak cukup untuk membiayai penyakit tertentu yang diderita oleh pasien peserta JKN sehingga dokter terpaksa harus memulangkan pasien dalam kondisi yang belum betul-betul sembuh karena pagu anggarannya telah habis (tidak cukup). Keputusan dokter dan rumah sakit memulangkan pasien bertujuan menghindari kerugian rumah sakit, sekaligus dengan harapan pasien dapat kembali ke rumah sakit untuk melanjutkan pengobatannya dengan pagu tarif yang baru. Ketika dokter

${ }^{1}$ Hikmatul dan Nurhidayah, Arah, Tujuan dan Sasaran Kebijakan Kesehatan, Jakarta, 2011, hlm. 13. 
memulangkan pasien secara medis dokter bisa membayangkan ada potensi kambuhnya penyakit saat pasien berada di rumah, potensi itu merupakan suatu kemungkinan yang bisa membahayakan jiwa pasien ketika berada di rumah.

Tindakan dokter memulangkan pasien dalam kondisi tersebut, dapat dikatakan melanggar standar pelayanan medis dan standar prosedur operasional karena kewajiban untuk memberikan upaya pelayanan kesehatan (inspaning verbintensi) tidak dilaksanakan secara maksimal, karena berdasarkan standar pelayanan medis dan standar pelayanan operasional dokter wajib mengikuti seluruh tahapan dan langkah-langkah medis yang telah ditentukan sampai pasien sembuh. Tindakan ini secara medis membahayakan keselamatan pasien tetapi dokter dan rumah sakit dibatasi oleh pola tarif yang sudah ditetapkan dalam INA-CBGs. ${ }^{2}$

Sebagai contoh kasus pemulangan pasien dalam kondisi belum sembuh pernah terjadi di rumah sakit Al-Ihsan Bandung. Salah satu dokter pernah menangani kasus Respiratory Failure (gagal pernafasan). Dalam standar pelayanan medik (SPM) yang dibuat oleh kolegium Respiratory Failure yang disebabkan karena penyakit Paru Obstruksi Kronis (PPOK) maka lama perawatan yang dibutuhkan berkisar 2-3 minggu agar pasien betul-betul sembuh dan obat antibiotik yang diberikan adalah antibiotik dari generasi ke $4 .^{3}$

Dokter berharap dengan pagu anggaran yang ada bisa mengobati pasien semaksimal mungkin, tetapi karena tarif INA-CBGs tidak mencukupi maka lama rawat inap yang diberikan umumnya hanya berkisar 10 hari dan antibiotik yang diberikan adalah antibiotik generasi ke 2. Dengan demikian telah terjadi pelanggaran SPM/ modifikasi SPM dan akhirnya pasien dipulangkan pada hari ke 10 dalam keadaan yang umumnya belum sembuh. Kasus Respiratory Failure yang disebabkan oleh PPOK yang dipulangkan dalam keadaan belum pulih ternyata menimbulkan kekambuhan ketika pasien berada di rumah.

Resiko ini secara medis telah diperkirakan oleh dokter dan rumah sakit, tetapi karena pelayanan pasien JKN harus mengikuti sistem yang sudah baku,

${ }^{2}$ Riski Novela, Hubungan Pasien dengan Dokter dalam Kepesertaan JKN, Jurnal Kesehatan Komunitas, Vol 3 No 3 April 2017, hlm 73

${ }^{3}$ Hasil Wawancara dengan Tim Dokter spesialis Paru Rumah Sakit Al-Ihsan Provinsi Jawa Barat Tanggal 28 November 2018. 
maka dokter dan rumah sakit terpaksa harus memulangkan pasien terlebih dahulu dengan tujuan agar memperoleh pagu baru sehingga pasien mendapatkan pengobatan yang menyembuhkan penyakitnya. Pada saat pasien dipulangkan dokter telah memberikan instruksi agar segera membawa ke rumah sakit apabila terjadi tanda-tanda kekambuhan penyakit. Instruksi ini disampaikan untuk mengantisipasi keadaan yang membahayakan kesehatan pasien.

Problem yuridis yang timbul dalam konteks ini mungkinkah dokter dapat dikatakan telah melakukan perbuatan melawan hukum di mana perbuatan yang karena kesalahannya menimbulkan kerugian bagi pasien rumah sakit. Perbuatan yang disebabkan karena kesalahan dan menimbulkan kerugian ini apakah dipandang sebagai hubungan kausalitas yang mewajibkan dokter di rumah sakit harus bertanggung jawab secara hukum, tetapi meskipun demikian kesalahan berupa tindakan memulangkan pasien dalam kondisi belum sembuh bukan sebuah keputusan medis yang bersifat absolut dari dokter melainkan karena pengaruh sistem yang "memaksa" dokter harus memulangkan pasien dengan harapan agar pasien dapat kembali ke rumah sakit untuk mendapatkan perawatan paripurna dengan pagu biaya yang kembali utuh sesuai keadaan penyakitnya.

\section{Identifikasi Masalah}

Artikel ini akan membahas bagaimana pelaksanaan pelayanan medis oleh dokter di rumah sakit berdasarkan ketentuan JKN dihubungkan dengan Pasal 50 dan 51 Undang-Undang No 29 Tahun 2004 Tentang Praktik Kedokteran, dan Bagaimana bentuk kebijakan perlindungan hukum yang dapat memberikan kepastian hukum bagi dokter di rumah sakit yang menjalankan pelayanan JKN untuk menciptakan rasa aman dan ketertiban dalam pelayanan kedokteran?

\section{Metode Penelitian}

Metode penelitian dalam penulisan ini menggunakan pendekatan yuridis normatif karena mengkaji peraturan perundang-undangan yang mengatur perlindungan hukum terhadap dokter dalam Undang-Undang No 29 Tahun 2004 
tentang Praktik Kedokteran dengan menggunakan data sekunder melalui teknik studi kepustakaan dan dianalisis secara kualitatif.

\section{B. PEMBAHASAN}

\section{a. Pelaksanaan Pelayanan Medis oleh Dokter di Rumah Sakit Berdasarkan Ketentuan JKN Dihubungkan dengan Pasal 50 dan 51 Undang-Undang No. 29 Tahun 2004 Tentang Praktik Kedokteran}

Untuk mendapatkan perlindungan hukum seorang dokter harus menjalankan kewajiban klinis sesuai yang diamanatkan Pasal 51 huruf a Undang-Undang No 29 Tahun 2004 tentang Praktik Kedokteran bahwa:

"Dokter atau dokter gigi dalam melaksanakan praktik kedokteran mempunyai kewajiban memberikan pelayanan medis sesuai dengan standar profesi dan standar prosedur operasional serta kebutuhan medis pasien “

Kewajiban ini melekat bagi setiap dokter yang menjalankan praktik kedokteran karena sebagai seorang profesional mereka terikat dengan aturan-aturan di bidang kedokteran sebagai acuan untuk mengukur kualitas mutu pelayanan medis. Apabila dokter telah menjalankan tugas dan kewajibannya sesuai standar pelayanan medis dan standar pelayanan operasional maka secara hukum berhak mendapat perlindungan hukum. Norma hukum yang bisa digunakan tolak ukur kapan dokter berhak atas perlindungan hukum diatur dalam Pasal 50 huruf a Undang-Undang No 29 Tahun 2004 tentang Praktik Kedokteran apabila:

"Dokter atau dokter gigi dalam melaksanakan praktik kedokteran mempunyai hak memperoleh perlindungan hukum sepanjang melaksanakan tugas sesuai dengan standar profesi dan standar prosedur operasional"

Pengertian "standar profesi" menurut Penjelasan Pasal 50 UU Praktik Kedokteran adalah batasan kemampuan (knowledge, skill and professional attitude) minimal yang harus dikuasai oleh seorang individu untuk dapat melakukan kegiatan profesionalnya pada masyarakat secara mandiri yang dibuat oleh organisasi profesi, sedangkan yang dimaksud dengan "standar prosedur operasional" adalah suatu perangkat instruksi/langkah-langkah yang dibakukan untuk menyelesaikan suatu proses kerja rutin tertentu. Standar prosedur operasional 
memberikan langkah yang benar dan terbaik berdasarkan konsensus bersama untuk melaksanakan berbagai kegiatan dan fungsi pelayanan yang dibuat oleh sarana pelayanan kesehatan berdasarkan standar profesi.

Aturan dalam Pasal 50 huruf a di atas tegas memberikan acuan bagi dokter untuk bisa dilindungi wajib menjalankan pelayanan kedokteran sesuai standar pelayanan medis dan operasional. Artinya secara normatif dokter berhak atas perlindungan hukum sepanjang dalam menjalankan praktik tidak menyimpang dari standar pelayanan medis dan operasional yang telah ditetapkan rumah sakit. Sebaliknya bila terjadi penyimpangan maka dokter tidak memiliki dasar yang kuat untuk mendapat perlindungan karena telah nyata melakukan kesalahan.

Kesalahan menjadi unsur yang esensial dalam menentukan apakah seseorang harus mempertanggungjawabkan perbuatannya atau tidak. Dalam hukum pidana dikenal asas "tiada pidana tanpa kesalahan" (geen straf zonder schuld). asas ini merupakan prinsip utama dalam menentukan pertanggungjawaban hukum secara pidana. Unsur kesalahan dalam diri pelaku tindak pidana inilah yang akan menjadi dasar pertimbangan bagi hakim atau syarat umum untuk menjatuhkan pidana. $^{4}$

Permasalahan hukumnya dokter yang memberikan pelayanan kedokteran dengan sadar melakukan penyimpangan terhadap tahapan-tahapan tindakan medis yang seharusnya tetapi tindakan itu dilakukan tanpa niat jahat (mens rea). Dasar tindakan itu dilakukan adalah untuk menghindari kerugian rumah sakit karena pagu tarif INA CBGs dalam kasus tertentu tidak dapat mengcover seluruh biaya rawat dan obat pasien. Sebagai contoh kasus pemulangan pasien sebelum penyakitnya betul-betul sembuh yang disebabkan karena pagu tarifnya tidak mencukupi, akhirnya dokter mengambil keputusan untuk memulangkan pasien dengan tujuan agar pasien mendapatkan pagu tarif yang penuh setelah kembali di rawat di rumah sakit.

${ }^{4}$ Roni Wiyanto, Asas-asas Hukum Pidana, Mandar Maju, Bandung, 2012, Hlm 182 
Tindakan memulangkan pasien sebelum sembuh secara prosedural melanggar, karena dokter tidak memberikan hak pasien atas kebutuhan medis sebagaimana diatur dalam Pasal 51 huruf a Undang-Undang Praktik Kesehatan, tetapi bila perawatan dilanjutkan maka rumah sakit harus menanggung kekurangan biaya yang tidak tercover oleh INA CBGs. Secara hukum perbuatan dokter memulangkan pasien bisa dikategorikan melawan hukum (unlawful) karena menyimpang dari prosedur tetapi dilihat dari sikap batin dokter tidak memiliki niat untuk mencelakai pasien.

Dalam hukum pidana terdapat alasan yang dapat menghapuskan pertanggungjawaban pidana berupa alasan pemaaf dan alasan pembenar. Alasanalasan tersebut telah diakui dan diatur dalam KUHP. Alasan pemaaf menjelaskan seseorang yang melakukan perbuatan melawan hukum dipandang tidak bersalah apabila pembuatnya tidak dapat dipertanggungjawabkan seperti orang yang terganggu jiwanya dan anak di bawah umur (Pasal 44, 45), daya paksa (Pasal 48 KUHP), pembelaan darurat yang melampaui batas (Pasal 49 ayat 2 KUHP), perintah jabatan (Pasal 51 ayat 2 KUHP). ${ }^{5}$

Disamping alasan pemaaf, hukum pidana mengenal alasan pembenar sebagai dasar untuk menghapus sifat melawan hukum dari perbuatan sehingga awalnya dipandang sebagai perbuatan melawan hukum tetapi kemudian dibenarkan seperti keadaan darurat (Pasal 48 KUHP), pembelaan darurat (Pasal 49 ayat 1), menjalankanUU (Pasal 50 KUHP), perintah jabatan (Pasal 51 ayat 1). ${ }^{6}$

Sejalan dengan perkembangan modernitas ilmu pengetahuan dan teknologi maka tuntutan pasien terhadap pelayanan kedokteran juga semakin tinggi pengharapannya bagi keberhasilan upaya pengobatan ini merupakan hal yang wajar dan dapat dimengerti karena rumah sakit yang menerapkan upaya pelayanan medis berdasarkan hasil perkembangan teknologi terkini yang didukung oleh SDM memadai serta fasilitas pelayanan yang menunjang pada umumnya akan memenuhi

${ }^{5}$ Andi Hamzah, Asas-asas Hukum Pidana, Rineka Cipta, Jakarta, 2008, HIm 155.

${ }^{6}$ Andi Hamzah, Perbandingan Hukum Pidana, Sinar Grafika, Jakarta, 2008, HIm 281. 
harapan (Inspanning Verbin Result) sehingga memberikan rasa puas bagi pasien (patient satisfaction). ${ }^{7}$

Dalam hal pelayan medis oleh dokter di rumah sakit pada era JKN kemajuan ilmu dan teknologi kedokteran tidak serta merta menjadikan pelayanan medis tersebut menjadi meningkat mutunya secara signifikan karena dalam pelayanan medis JKN dikenal dengan istilah kendali mutu dan kendali biaya. Artinya bagaimana pelayanan medis yang diberikan secara rasional dengan mengikuti kebijakan pola tarif INA CBGs, yaitu pelayan medis yang dijalankan dalam bentuk paket layanan yang didasarkan kepada pengelompokan diagnosis bebas penyakit dan prosedur dengan klaim pembayaran sesuai dengan besaran pagu tarif INA CBGs (Permenkes No 59/2014). Oleh karena pada pelayanan medis JKN harus selalu menyesuaikan dengan besaran pagu tarif yang sudah ditentukan maka hal terpenting yang dijadikan sebagai panduan layanan adalah clinical pathway dimana alur tata klinisnya sudah sesuai dengan besaran pola tarif INA CBGs, namun sayangnya clinical pathway yang dibuat oleh rumah sakit lebih mengutamakan ketepatan alur tata klinis layanan dengan besaran pagu tarif INA CBGs dibanding dengan standar pelayanan kedokteran yang ditetapkan Kemenkes (Permenkes No 1438 Tahun 2010), sehingga pada pelayanan medis dengan ketentuan JKN dapat dihasilkan pelayanan yang sesuai dengan clinical pathway namun belum tentu sesuai dengan standar pelayanan kedokteran yang dalam hal ini adalah SPO dan SPM. Bila hal ini dihubungkan dengan Pasal 50 huruf b Undang-Undang No 29 Tahun 2004 Tentang Praktik Kedokteran bahwa:

"Dokter atau dokter gigi dalam melaksanakan praktek kedokteran mempunyai hak memberikan pelayanan medis menurut standar profesi dan standar prosedur operasional".

Ini bermakna bahwa dokter dalam menjalankan pelayanan medis baik pelayanan JKN maupun pelayanan medis umum, mempunyai hak untuk melaksanakan pelayanan medis sesuai dengan langkah-langkah yang dibakukan dalam panduan praktek klinik. Menurut kamus Bahasa Indonesia pengertian hak

\footnotetext{
${ }^{7}$ Ratna Artha Windari, Hukum Perjanjian, Graha Ilmu, Yogyakarta, 2018, hlm. 63
} 
adalah sesuatu yang benar, milik, kepunyaan, kewenangan dan kekuasaan seseorang untuk berbuat sesuatu karena telah diatur oleh undang undang atau peraturan lainnya.

Penjelasan tersebut dapat disimpulkan bahwa definisi hak adalah sesuatu yang mutlak menjadi milik kita dimana penggunaan hak tersebut tergantung kepada diri kita sendiri. Dengan demikian dapat dikatakan bahwa pengertian Pasal 50 huruf b UUPK bermakna "Dalam menjalankan praktek kedokteran, dokter mempunyai kewenangan mutlak untuk memberikan pelayanan medis sesuai standar profesi dan standar operasional."

Bila pengertian hak ini diaplikasikan secara penuh dan dipahami oleh seluruh pihak terkait dalam sistem pelayanan kedokteran, maka pelaksanaan pelayanan medis yang sesuai SPO tidak boleh dibatasi oleh ketentuan besaran pagu tarif seperti layaknya pelayanan medis JKN yang harus sesuai dengan pagu tarif INA CBGs. Sebagaimana fakta pelayanan medis saat ini di rumah sakit Kelas B yang diteliti ternyata dokter melaksanakan pelayanan medis JKN dengan harus mematuhi kebijakan rumah sakit dan kebijakan BPJS dimana pelayanan medis harus sesuai dengan pagu tarif peruntukan sesuai yang ada dalam panduan clinical pathway. Ketika menjalankan pelayanan pada kasus-kasus tertentu yang berbiaya tinggi seperti stroke karena faktor pendarahan serta kasus gagal pernapasan yang disebabkan oleh PPOK dan ternyata tarif INA CBGs-nya tidak sesuai atau lebih rendah dari total cost kasus tersebut maka berpotensi untuk tidak dijalankannya SPO dan SPM pada upaya pelayanan medisnya. Dokter tidak berdaya untuk menggunakan haknya karena bila hak itu digunakan dengan menjalankan pelayanan medis JKN sesuai SPO dan SPM maka dapat beresiko sanksi bagi dokter untuk tidak mendapatkan jasa pembayaran/dikurangi jasa pembayarannya, karena pelayanan yang melebihi pagu tarif yang telah ditetapkan dapat beresiko merugikan rumah sakit.

Kondisi ini cukup dilematis bagi dokter sebagai pelaksana kebijakan JKN sehingga untuk menghindari konflik internal batin dokter dan pemberian pelayanan medis bagi pasien dengan mutu yang baik serta keselamatan pasien maka pelaksanaan pelayanan medis dengan ketentuan JKN harus mengikuti ketentuan Pasal 50 huruf b UUPK dimana dokter diberi kewenangan untuk menjalankan 
pelayanan medis sesuai SPO walaupun beresiko untuk melampaui besaran pagu tarif peruntukan. Namun dengan catatan SPO dan SPM yang dijalankan harus logis dan sesuai dengan penjabaran dalam clinical pathwaynya. Sebagai langkah tindak lanjut pelayanan medis yang sesuai dengan SPO dan clinical pathwaynya maka perlu ada evaluasi dan perbaikan dari pola pagu tarif INA CBGs yang dilaksanakan oleh Nasional Casemix Center (NCC) Kementerian kesehatan.

Penjelasan ini menunjukkan bahwa dalam pelaksanaan pelayanan kesehatan oleh dokter di rumah sakit berdasarkan ketentuan JKN dokter ada pada posisi Overmacht (keterpaksaan) untuk menjalankan pelayanan yang clinical pathwanya mengikuti pagu tarif yang telah ditentukan dan aturan tersebut telah merampas hak dokter untuk memberikan pelayanan medis sesuai standar profesi yang berakibat pada tidak terpenuhinya hak pasien untuk mendapatkan pelayanan medis yang baik. Overmacht R Sugandhi menjelaskan bahwa kalimat "karena pengaruh daya paksa" harus diartikan pengaruh daya paksa lahir maupun batin, rohani dan jasmani. ${ }^{8}$

\section{b. Kebijakan Perlindungan Hukum bagi Dokter di Rumah Sakit yang Menjalankan Pelayanan Jaminan Kesehatan Nasional untuk Menciptakan \\ Rasa Aman dan Ketertiban Pelayanan Medis}

Kebijakan hukum sudah sepatutnya memberikan perlindungan bagi profesi dokter yang terus memperjuangkan dan mengabdikan profesinya untuk kesehatan masyarakat. Olah karena itu, negara sudah sepatutnya membuat kebijakan perlindungan hukum bagi dokter di rumah sakit dalam menjalankan pelayanan JKN. Bertolak dari teori kebijakan dan perlindungan hukum ada 2 (dua) model perlindungan yang dapat digunakan untuk memberikan keamanan bagi dokter untuk tetap menjalankan program JKN berupa:

\section{a. Perlindungan Hukum Preventif}

Perlindungan hukum preventif memiliki pengertian bahwa setiap subjek hukum berhak untuk dilindungi sebelum terjadinya pelanggaran. Menurut penulis

${ }^{8}$ Kansil, Latihan Ujian Hukum Pidana, Sinar Grafika, Jakarta, 2010, HIm 32 
sumber persoalan yang menyebabkan dokter harus memberikan pelayanan kedokteran yang sesuai dengan pola pagu tarif ada pada kebijakan pola tarif INA CBGs yang harus disesuaikan dengan Standar Pelayanan Medis, kebijakan ini membuat rumah sakit harus menyusun Standar Pelayanan Medis dan Standar Prosedur Operasional yang menyesuaikan dengan pagu tarif yang telah ditetapkan Kementerian Kesehatan, padahal dari segi keilmuan profesi dokter, tindakan medis itu bersumber dari ilmu pengetahuan kedokteran yang kurang baik bila dibatasi/diukur dengan jumlah tarif tertentu. Atas dasar itu, Standar Pelayanan Medis dan Standar Prosedur Operasional di beberapa rumah sakit tertentu dapat dikatakan bermasalah atau tidak tergantung kesesuaiannya dengan kaidah Pedoman Nasional Pelayanan Kedokteran (PNPK), jika standar yang dibuat dan digunakan tidak sesuai maka sudah pasti pada tahap pelaksanaan pemberian pelayanan kesehatan bagi pasien JKN tidak sesuai dengan kebutuhan medis pasien karena secara prosedur ada tahapan yang mungkin tidak dilalui. Keadaan ini seperti yang telah dijelaskan sebelumnya membuat posisi dokter berpotensi dituntut secara hukum.

Berdasarkan hal tersebut maka dokter dalam menjalankan kebijakan pelayanan JKN sangat membutuhkan perlindungan hukum yang dapat mencegahnya agar tidak melakukan tindakan yang mengarah pada malpraktik sehingga dapat menimbulkan rasa aman serta ketertiban dalam pelayanan kedokteran. Perlindungan hukum yang bersifat preventif memberikan tawaran jalan keluar untuk mencegah terjadinya penyimpangan standar pelayanan medis dengan cara:

Pertama, Kementerian Kesehatan sebagai lembaga yang berwenang perlu membuat Pedoman Nasional Pelayanan Kedokteran (PNPK) yang disesuaikan dengan pola tarif INA CBGs secara rasional. Pola tarif INA CBGs yang berlaku saat ini dinilai ada beberapa yang tidak rasional bila dihubungkan dengan jenis penyakit-penyakit tertentu yang ditangani sesuai dengan tipologi rumah sakit. Penyesuaian pola tarif ini penting untuk menghindari kasus penyakit yang habis pagu anggarannya sebelum selesai pengobatan sehingga terpaksa dipulangkan. Bila kebijakan penetapan tarif tidak dikaji secara cermat dan hati-hati bisa menimbulkan masalah-masalah medis dan yuridis pada tataran implementasi.

Kedua, Kementerian Kesehatan perlu membuat PNPK tatalaksana yang menyesuaikan dengan tipologi rumah sakit. Rumah sakit harus memiliki SPM yang 
sesuai jenis dan kelasnya. Dalam artian tidak boleh terjadi pembuatan SPM dalam implementasinya di rumah sakit dengan cara penyamaan dengan rumah sakit rujukan nasional sehingga tidak terjadi penyamaan SPM rumah sakit kelas A untuk kelas B atau kelas C. Walaupun telah dimodifikasi secara tersendiri oleh masing- masing rumah sakit. Beberapa dasar pemikiran pembuatan PNPK tatalaksana/Standar Pelayanan Medis harus dibuat oleh Kementerian Kesehatan adalah:

1. Undang undang No. 29 Tahun 2004 tentang praktek kedokteran Pasal 44 ayat (2): standar pelayanan kedokteran dibedakan menurut jenis dan strata sarana pelayanan kesehatan. Ini berarti PNPK Tatalaksana harus sesuai dengan tipologi Rumah Sakit (jenis dan strata sarana pelayanan). Pasal 44 ayat (3): Standar pelayanan kedokteran untuk dokter dan dokter gigi diatur dengan peraturan menteri. Ini berarti seluruh PNPK Tatalaksana yang menjadi pedoman Rumah sakit untuk praktek pelayanan medis dikeluarkan dan ditetapkan oleh menteri kesehatan (Kepmenkes).

2. National Casemix Center (NCC) sudah membuat dan mengeluarkan panduan pola tarif INA CBGs yang sudah disesuaikan pula dengan tipologi Rumah Sakit.

3. Tarif INA CBGs yang dibuat oleh NCC sudah tentu berdasarkan Diagnosa Penyakit, SPM. SPO, dan Clinical Pathway kasus penyakitnya

Proses pembuatan SPM dengan cara penyamaan secara nyata terjadi di era JKN, hal ini dapat menimbulkan permasalahan ketika membuat SPO yang menjadi panduan untuk menentukan langkah-langkah keputusan pelayanan medis. Keadaan ini sangat berpotensi menimbulkan masalah hukum bila pelayanan medis yang dilaksanakan menimbulkan kerugian bagi pasien karena tidak sesuai dengan PNPK tatalaksana yang seharusnya dijadikan dasar dalam penyusunan langkah-langkah tindakan medis/Standar Prosedur Operasional medis.

\section{b. Perlindungan Hukum Represif}

Salah satu Peraturan perundang-undangan yang mengatur tentang perlindungan hukum dokter dalam memberikan pelayanan medis adalah Pasal 78 Undang-Undang No 36 Tahun 2014 tentang Tenaga Kesehatan menegaskan bahwa: 
"Dalam hal tenaga kesehatan diduga melakukan kelalaian dalam menjalankan profesinya yang menyebabkan kerugian kepada penerimaan pelayanan kesehatan, perselisihan yang timbul akibat kelalaian tersebut harus diselesaikan terlebih dahulu melalui penyelesaian sengketa di luar pengadilan sesuai ketentuan peraturan perundang-undangan"

Ketentuan ini mengatur bahwa segala kerugian pasien yang disebabkan pelayanan kedokteran harus diselesaikan terlebih dahulu melalui penyelesaian sengketa di luar pengadilan. Alternative dispute resolution (ADR) atau alternatif penyelesaian sengketa (APS) merupakan upaya penyelesaian sengketa di luar litigasi (non-litigasi). Dalam ADR/APS terdapat beberapa bentuk penyelesaian sengketa. Bentuk-bentuk ADR/APS menurut Suyud Margono adalah (1) konsultasi; (2) negosiasi; (3) mediasi; (4) konsiliasi; (5) arbitrase. ${ }^{9}$

Bentuk ADR/APS dalam Undang-Undang No 30 Tahun 1999 tentang Arbitrase dan Alternatif Penyelesaian Sengketa adalah konsultasi, negosiasi, mediasi, konsiliasi atau penilaian ahli. Tidak dijabarkan lebih lanjut pengertian dari masing-masing bentuk ADR/APS tersebut dalam UU No. 30/1999. Adapun, arbitrase dikeluarkan dari lingkup ADR/APS dan diberikan definisi tersendiri dalam UU No 30/1999 yakni:

"Cara penyelesaian suatu sengketa perdata di luar peradilan umum yang didasarkan pada perjanjian arbitrase yang dibuat secara tertulis oleh para pihak yang bersengketa".

Bentuk penyelesaian sengketa medik melalui alternatif penyelesaian secara tegas disebutkan dalam Pasal 29 Undang-Undang No 36 Tahun 2009 tentang Kesehatan yang menegaskan bahwa:

Dalam hal tenaga kesehatan diduga melakukan kelalaian dalam menjalankan profesinya, kelalaian tersebut harus diselesaikan terlebih dahulu melalui mediasi

Pengertian mediasi adalah penyelesaian sengketa dengan dibantu oleh pihak ketiga (mediator) yang netral/tidak memihak. Peranan mediator adalah sebagai penengah (pasif) yang memberikan bantuan berupa alternatif-alternatif

\footnotetext{
${ }^{9}$ Ros Angesti Anas Kapindha, dkk, "Efektivitas dan Efisiensi Alternative Dispute Resolution (ADR) Sebagai Salah Satu Penyelesaian Sengketa Bisnis di Indonesia”, Privat Law 1 2, No. 4 (2014), Hlm 7.
} 
penyelesaian sengketa untuk selanjutnya ditetapkan sendiri oleh pihak yang bersengketa. ${ }^{10}$ Dalam Peraturan Mahkamah Agung No. 1 Tahun 2016 tentang Prosedur Mediasi di Pengadilan, mediasi diberikan arti sebagai cara penyelesaian sengketa melalui proses perundingan untuk memperoleh kesepakatan para pihak dengan dibantu oleh mediator.

Penyelesaian sengketa medis melalui mediasi sebagaimana disebutkan dalam Pasal 29 memberikan ruang bagi dokter untuk menghindari proses hukum yang panjang dan melelahkan dan mengancam profesinya yang banyak dibutuhkan masyarakat. Mediasi menjadi perlindungan hukum represif yang dapat ditempuh untuk menyelesaikan tuntutan hukum.

Perlindungan hukum represif melalui mediasi memberikan manfaat bagi para pihak yang berselisih. Mediasi perlu diupayakan untuk mencapai kesepakatan perdamaian antara dokter dan pasien. Mediasi bukan merupakan saran yang muncul secara tiba-tiba melainkan berdasarkan pemikiran penulis melalui proses ilmiah yang bersandar pada teori kebijakan dan perlindungan hukum yang telah dikemukakan pada bab sebelumnya. Secara singkat analisis yang melahirkan konsep mediasi dapat dijelaskan sebagai berikut:

Pertama, dokter sebagai profesi yang melaksanakan kebijakan JKN di rumah sakit diharuskan mengikuti clinical pathway yang disesuaikan dengan pagu tarif INA CBGs yang mana setiap langkah medis tidak boleh menyimpang dari ketentuan tarif JKN untuk setiap jenis penyakit yang sudah ditetapkan Kemenkes. Kewajiban itu dalam tataran teknis ditetapkan oleh Direktur rumah sakit yang harus dipatuhi oleh semua dokter dalam memberikan pelayanan medis kepada pasien JKN.

Kedua, kewajiban dokter mengikuti clinical pathway yang harus menyesuaikan dengan pagu tarif INA CBGs membuat dokter tidak bisa menggunakan haknya secara penuh sebagai profesional untuk memberikan pelayanan medis menurut standar profesi dan standar prosedur operasional. Ini terjadi karena pelayanan medis yang sesuai dengan standar profesi untuk kasus

\footnotetext{
${ }^{10}$ Marwah Diah, Penyelesaian Sengketa, Pustaka Pelajar, Bandung, 2018, Hlm 117.
} 
penyakit tertentu tidak bisa dibatasi oleh tarif INA CBGs karena untuk menghasilkan mutu medis yang baik membutuhkan biaya cukup besar dan melampaui pagu tarif, apabila dokter mengikuti clinical pathway yang menyesuaikan dengan pagu tarif INA CBGs dapat dipastikan mutu medis yang dihasilkan tidak akan sesuai dengan apa yang diharapkan oleh pasien karena proses perawatannya tidak dilakukan dengan tuntas yang berakibat pasien tidak sembuh bahkan meninggal dunia. Penulis menilai ketentuan JKN yang mengharuskan dokter mengikuti pola tarif ini tidak melindungi hak dokter untuk memberikan pelayanan medis menurut standar profesi sebagaimana dijelaskan dalam Pasal 50 huruf b Undang-Undang Praktik Kedokteran karena dokter dalam melayani pasien dengan kasus-kasus penyakit tertentu dibatasi haknya. ${ }^{11}$

Ketiga, posisi dokter selain tidak mendapat haknya sesuai Pasal 50 huruf b Undang-Undang Praktik Kedokteran juga tidak dapat menjalankan kewajiban memberikan pelayanan medis sesuai dengan standar profesi dan standar prosedur operasional serta kebutuhan medis pasien sesuai Pasal 51 huruf a, sementara Pasal 79 Undang-Undang Praktik Kedokteran mengancam dengan pidana kurungan paling lama 1 (satu) tahun atau denda paling banyak Rp 50.000.000,00 (lima puluh juta rupiah), bagi setiap dokter yang tidak menjalankan kewajiban.

Keempat, tidak diperolehnya hak dan kewajiban dokter dalam memberikan pelayanan medis kepada pasien JKN membuat dokter pada kondisi yang disebut "Overmacht" atau daya paksa. Istilah overmacht dikenal dalam hukum pidana sebagai salah satu alasan yang menghapuskan pertanggungjawaban pidana. Artinya KUHP menerima keadaan-keadaan tertentu yang memungkinkan seorang pelaku tindak pidana tidak dapat dipertanggungjawabkan atau tidak dapat dijatuhi pidana. ${ }^{12}$ Overmacht diatur dalam Pasal 48 KUHP mengatur bahwa “orang yang melakukan tindak pidana karena pengaruh daya paksa, tidak dipidana".

${ }^{11}$ Riski Novela, Hubungan Pasien dengan Dokter dalam Kepesertaan JKN, Jurnal Kesehatan Komunitas, Vol 3 No 3 April 2017, Hlm 73

${ }^{12}$ Nandang Sambas dan Ade Mahmud, Perkembangan Hukum Pidana, Refika Aditama, Bandung, 2019, Hlm 181-182 
Aturan ini dapat diterapkan bagi dokter yang melaksanakan pelayanan kesehatan JKN di rumah sakit karena mereka dihadapkan pada pilihan apakah akan menjalankan clinical pathway yang SPM dan SPOnya ditetapkan Kemenkes dengan resiko melampaui pagu tarif atau mengacu pada clinical pathway yang tata klinisnya menyesuaikan dengan tarif INA CBGs dengan resiko pasien tidak sembuh atau bertambah parah dan berpotensi menimbulkan tuntutan hukum. Dalam praktek dokter lebih condong menggunakan clinical pathway yang mengikuti pagu tarif INA CBGs karena apabila mengikuti clinical pathway yang mengacu pada SPM dan SPO yang ditetapkan Kemenkes, pagu tarif yang disediakan tidak akan cukup untuk mengcover biaya perawatan pasien dalam hal penyakit tertentu yang membutuhkan biaya yang tinggi. Apabila biaya perawatan melampaui pagu tarif INA CBGs rumah sakit akan mengalami kerugian dan pembayaran jasa pelayanan dokter terancam tidak atau dikurangi oleh rumah sakit karena BPJS hanya membayar biaya pelayanan medis yang sesuai pagu tarif INA CBGs. Keadaan ini dapat dikatakan overmacht relatif karena dokter masih bisa mengambil pilihan lain tetapi kinerja dokter dalam memberikan pelayanan kesehatan tidak diberikan penghargaan, tetapi kondisi tersebut bisa dijadikan dasar untuk meniadakan pertanggungjawaban pidana karena menunjukkan keadaan yang memaksa dokter melakukan tindakan yang "melanggar standar profesi".

Kelima, Keadaan overmacht yang dihadapi dokter dalam memberikan pelayanan medis kepada pasien JKN ini tidak tepat apabila diselesaikan dengan tuntutan hukum perdata maupun pidana karena keadaan overmacht ini harus dijelaskan oleh dokter kepada pasien atau keluarganya dalam forum mediasi yang independen dan otonom yang dilaksanakan MKDKI dengan susunan 3 (tiga) orang dokter dan 3 (tiga) orang dokter gigi dari organisasi profesi masing-masing, seorang dokter dan seorang dokter gigi mewakili asosiasi rumah sakit, dan 3 (tiga) orang sarjana hukum. Untuk merealisasikan penyelesaian sengketa medis melalui mediasi perlu ada kebijakan perlindungan hukum bagi dokter dalam melaksanakan pelayanan medis terhadap pasien JKN di rumah sakit. Kebijakan 
perlindungan hukum tersebut ditempuh dengan cara menambah kewenangan MKDI dalam Undang-Undang No 29 Tahun 2004 Tentang Praktik Kedokteran untuk mengadakan mediasi dan menjelaskan posisi dokter kepada pasien tentang kondisi yang sebenarnya dengan tujuan supaya mereka mengerti posisi dokter sehingga kasus tersebut dapat diselesaikan secara kekeluargaan.

Penguatan lembaga MKDKI melalui penambahan kewenangan untuk menjalankan mediasi di tengah masyarakat yang kritis terhadap pelayanan kesehatan menjadi suatu keniscayaan karena dokter di rumah sakit rentan untuk berhadapan dengan tuntutan hukum terutama sejak berlakunya kebijakan JKN yang menerapkan sistem pola tarif INA CBGs yang belum mampu mengatasi secara menyeluruh pagu tarif yang rasional terhadap tindakan medis dalam pelayanan kedokteran.

Secara teoritik disamping teori perlindungan hukum preventif dan represif, dikenal pula konsep perlindungan hukum yang bersifat subjektif. Faiz Mufidi mengatakan bahwa perlindungan hukum subjektif bersumber dari informed consent berupa persetujuan yang diberikan oleh pasien atau keluarganya atas dasar penjelasan mengenai tindakan medis yang akan dilakukan terhadap pasien tersebut.13 Informed consent dilakukan secara lisan apabila tindakan medis itu tidak berisiko seperti pemberian terapi obat dan pemeriksaan penunjang medis, sedangkan untuk tindakan medis beresiko seperti pembedahan, maka informed consent dilakukan secara tertulis dan ditandatangani oleh pasien. Informed consent secara yuridis dipandang sebagai hukum yang tersebut dapat dijadikan bukti jika suatu saat muncul sengketa medis yang dapat digunakan dokter untuk melindungi diri dari tuntutan hukum.

\section{PENUTUP}

Pelaksanaan pelayanan medis berdasarkan ketentuan JKN menempatkan dokter pada situasi dilematis karena harus memberikan pelayanan berdasarkan clinical pathway yang alur tata klinisnya ditetapkan berdasarkan pola tariff INA CBGs. Kondisi ini membuat dokter sulit memperoleh hak untuk memberikan pelayanan medis menurut standar profesi dan standar prosedur operasional sebagaimana diatur dalam Pasal 50 
huruf $\mathrm{b}$ dan mempersempit kesempatan dokter untuk menjalankan kewajiban memberikan pelayanan medis sesuai dengan standar profesi dan standar prosedur operasional serta kebutuhan medis pasien sesuai Pasal 51 huruf a Undang- Undang No 29 Tahun 2004 Tentang Praktik Kedokteran. Apabila dalam kasus tertentu dokter memberikan pelayanan tidak sesuai dengan alur klinis INA CBGs akan beresiko tidak mendapatkan jasa pembayaran/dikurangi jasa pembayarannya, karena pelayanan yang diberikan melebihi pagu tarif yang telah ditetapkan dapat beresiko merugikan rumah sakit.

Kebijakan perlindungan hukum bagi dokter di rumah sakit yang menjalankan pelayanan JKN untuk menciptakan rasa aman dan ketertiban dalam pelayanan medis adalah:

1. Kebijakan perlindungan hukum yang bersifat preventif berupa pembuatan PNPK tatalaksana yang sudah disesuaikan dengan kebijakan pola tarif INA CBGs dan pembuatan SPM sesuai dengan tipologi rumah sakit (A, B, C), karena saat ini pola tarif INA CBGs yang sudah dibuat oleh National Casemix Centre (NCC) berdasarkan diagnosa penyakit dalam kelompok INA DRG berbasis pada SPM.

2. Kebijakan perlindungan hukum terhadap dokter di rumah sakit dalam melaksanakan pelayanan medis sesuai ketentuan JKN adalah dengan mengadakan upaya mediasi oleh MKDKI secara independen dan otonom agar menilai tuntutan hukum yang diajukan pasien atau keluarganya. Upaya mediasi dilaksanakan untuk menghindari tuntutan hukum malpraktik kepada dokter kecuali apabila mediasi tidak mencapai kesepakatan maka pasien atau keluarganya dapat mengajukan tuntutan pidana atau gugatan perdata ke pengadilan.

Untuk menghindari konflik internal batin dokter dan pemberian pelayanan medis bagi pasien dengan mutu yang baik serta keselamatan pasien maka pelaksanaan pelayanan medis dengan ketentuan JKN sebaiknya mengikuti ketentuan Pasal 50huruf b Undang-Undang No 29 Tahun 2004 Tentang Praktik Kedokteran dimana dokter diberi kewenangan menjalankan pelayanan medis sesuai SPO meskipun beresiko 
melampaui besaran pagu tarif peruntukan dengan catatan SPO dan SPM yang dijalankan harus logis dan sesuai dengan penjabaran dalam clinical pathway- nya. Sebagai langkah tindak lanjut pelayanan medis yang sesuai dengan SPO dan clinical pathway maka perlu ada evaluasi dan perbaikan dari pola pagu tarif INA CBGs yang dilaksanakan oleh Nasional Casemix Center (NCC) Kementerian kesehatan.

Untuk menyelesaikan sengketa yang timbul dari pelaksanaan pelayanan medis bagi pasien JKN sebaiknya Undang-Undang No 29 Tahun 2004 Tentang Praktik Kedokteran memberikan kewenangan kepada MKDKI untuk melaksanakan mediasi agar dokter bisa menjelaskan kondisi yang sesungguhnya kepada pasien sehingga dapat mengerti dan menghindari tuntutan hukum pidana maupun gugatan perdata di pengadilan. Penambahan kewenangan MKDKI untuk menjalankan mediasi merupakan kebijakan perlindungan hukum agar dokter mendapatkan rasa aman dalam memberikan pelayanan kesehatan bagi pasien JKN. 


\section{DAFTAR ISI}

\section{A. Buku}

Andi Hamzah, Asas-asas Hukum Pidana, Rineka Cipta, Jakarta, 2008. , Perbandingan Hukum Pidana, Sinar Grafika, Jakarta, 2008.

Hikmatul dan Nurhidayah, Arah, Tujuan dan Sasaran Kebijakan Kesehatan, Jakarta, 2011.

Kansil, Latihan Ujian Hukum Pidana, Sinar Grafika, Jakarta, 2010. Marwah Diah, Penyelesaian Sengketa, Pustaka Pelajar, Bandung, 2018.

Nandang Sambas dan Ade Mahmud, Perkembangan Hukum Pidana, Refika Aditama, Bandung, 2019.

Ratna Artha Windari, Hukum Perjanjian, Graha Ilmu, Yogyakarta, 2018. Roni Wiyanto, Asas-asas Hukum Pidana, Mandar Maju, Bandung, 2012.

\section{.B. Jurnal/Makalah}

Anna Ningsih, Pemukiman Kembali, Alternatif Ganti Kerugian bagi Riski Novela, Hubungan Pasien dengan Dokter dalam Kepesertaan JKN, Jurnal Kesehatan Komunitas, Vol 3 No 3 April 2017.

Riski Novela, Hubungan Pasien dengan Dokter dalam Kepesertaan JKN, Jurnal Kesehatan Komunitas, Vol 3 No 3 April 2017

Ros Angesti Anas Kapindha, dkk, "Efektivitas dan Efisiensi Alternative Dispute Resolution (ADR) Sebagai Salah Satu Penyelesaian Sengketa Bisnis Di Indonesia", Privat Law 1 2, No. 4 (2014).

\section{Peraturan Perundang-undangan}

Undang-Undang Dasar 1945

Kitab Undang-Undang Hukum Pidana

Undang-Undang No 29 Tahun 2004 Tentang Praktik Kedokteran

Undang-Undang No 36 Tahun 2014 tentang Tenaga Kesehatan 